
3 Research Square
Preprints are preliminary reports that have not undergone peer review.
They should not be considered conclusive, used to inform clinical practice, or referenced by the media as validated information.

\title{
Comparison of Forest Stand Condition Between Thinned and Unthinned Blocks Under Collaborative Forest Management of Western Lowlands of Nepal
}

\section{Kajol Belbase}

Kathmandu Forestry College, Tribhuvan University

Arun Sharma Poudel

Kathmandu Forestry College, Tribhuvan University

Sagar Godar Chhetri ( $\square$ sagargc44@gmail.com )

University of Georgia Warnell School of Forestry and Natural Resources

\section{Research}

Keywords: Regeneration, Collaborative, Thinned, Unthinned, Growing stock, Basal area

Posted Date: June 18th, 2020

DOI: https://doi.org/10.21203/rs.3.rs-35472/v1

License: (c) (i) This work is licensed under a Creative Commons Attribution 4.0 International License.

Read Full License

Version of Record: A version of this preprint was published at Small-scale Forestry on November 10th, 2022. See the published version at https://doi.org/10.1007/s11842-022-09534-8. 


\section{Abstract}

\section{Background}

After a successful implementation of community forestry practices, since 2003 collaborative forest management has been implementing in Nepal. Due to naive approaches of managing forest land in Nepal, the information regarding the forest condition under silviculture practices is very low. The purpose of the study was to understand the regeneration status in the harvested plot and make the comparison of crop stands between the thinned and unthinned plot.

\section{Method}

Harvested, Thinned, and Unthinned block of Tilaurakot Collaborative Forest was chosen for the study. Eccentric circular plots with radii $11.29 \mathrm{~m}$ was taken for trees, $5.64 \mathrm{~m}$ for poles, $2.82 \mathrm{~m}$ for saplings, and $1.78 \mathrm{~m}$ for seedling was taken to collect data from each of the selected blocks. Altogether, 71 plots were taken from harvested (11), thinned (30), and unthinned (30) block.

\section{Results}

The result shows seedling and sapling in the harvested block were 14,974 and 3,368 per hectare, respectively. Also, the study identified that the number of seedling and sapling in the thinned block were higher than the unthinned block. However, the growing stock and basal area per hectare in the thinned block were lower than the unthinned block. The number of trees per hectare was lesser in the thinned block (86 per ha) than an unthinned block (140 per ha). Similarly, the number of poles per hectare were lesser in the thinned block (346 per ha) than an unthinned block (370 per ha). Also, the important valve index (IVI) of Sal (Shorea robusta) was found more than other species in harvested, thinned, and unthinned blocks.

\section{Conclusions}

The study suggest that the condition of regeneration was better after the opening of the canopy and thinning promotes the growth of trees and undergrowth vegetation. Thus, policy makers should give emphasis on using the silvicultural operations in forest management to maintain the forest health.

\section{Background}

Collaborative forest management has been introduced by the Government of Nepal (GON) as new forest management approach which focuses on the large contiguous block of Terai and inner Terai of productive forest (Bampton et al. 2007). The purpose of the management system is to promote sustainable forest management and settle environmental, social, and political issues among stakeholders, including government concessionaires, communities, and national and international institutions. Also, CFM tries to include "closer" (users residing nearby forestlands) and "distance users" (users residing far away from forestlands) groups by providing alternative livelihood, creating 
employment opportunities for poor people dependent on forest, exploring indigenous knowledge and skills in forestry activities, and sharing benefits between the people and government. Revenue from the implementation of CFM scheme was mobilized for the management of forest and social development. It has improved good governance, through the public hearing, public audits, and institutional strengthening (Poudyal 2007). CFM practices scientific forest management (SFM) approaches to gain more benefits and noticeable improvement in forest condition.

In the past, scientific management of terai forest was not implemented expect few silvicultural demonstration plots (Parajuli and Amatya 2001). The condition of growing stock has deteriorated, leading to the predominance of growing stock with very low growth than potential growth and even good seed producing trees (Pesonen 1994; Rautiainen 1995). The total forest area of 3,654 hectares (ha) is available for improved management in which $S$. robusta forest covers $1,320,00$ ha of forest area in Nepal (Sowerine 1994). In some foothills district, the concept was slowly rolling out.

However, the concept of SFM was not a new concept; its principles originated in Germany at the beginning of the 19th century and adopted by forest training institutions and forestry bureaucracies (Kumar 2002; Rutt et al. 2014). SFM requires sound forest inventories that determine the growing stock and annual increment with sufficient accuracy to ensure harvesting does not exceed regrowth over the long term while maintaining environmental services such as erosion control watershed protection, wind protection species habitat and carbon storage (Rutt et al. 2014). SFM can contribute significantly to meeting the goal of sustainable development (FAO 2000). Application of SFM helps to create forest conditions improve environmental services, provide sustainable forest product to improve the local and national level economy and development, increase local level opportunities and development (MFSC 2014). The following result has been demonstrated in the scientifically managed forest within a short period:

- Profuse natural regeneration

- Improve forest conditions

- Increased of growing stock

- Revenue generation higher than investment

- Increase interest in and a better understanding of SFM.

- Impressive training and demonstration sites

- Increasing interest in and a better understanding of SFM

One of the major reasons of improved forest management is a practice of silvicultural system. The silviculture system is a planned program of silviculture treatment design to achieve a specific stand structure and fulfill the site objective of forest management. The treatment program integrates the harvesting, regeneration, and treatment method to obtain a predictable yield of benefits over time (BC 2003). Silviculture treatments have been practiced in CFM. Among several silvicultural operations, thinning is a popular and most integral activity in CFM. The aim of thinning was to achieve appropriate 
stand density and enhance diameter growth. Thinning helps to remove the poor-quality trees and is necessary where there is a dense growth of the plant with variation in growth and survival of plant species but trees that grow above and shade out small higher qualities trees thinning will be directed in such cases. Monitoring the growth rate of the trees is important to maintain a steady growth rate (Kenna and Woeste 2004).

One of the main reasons to opt Tilaurakot CFM is that the CFM has recently introduced a scientific forest management system and there is the number of harvested, thinned, and unthinned blocks. In Nepal, most of the studies on CFM focused on subjects such as benefits sharing mechanism (Rai et al. 2017), policy (Bampton et al. 2007), and implementation strategies (Paudyal 2007). However, knowledge and information on silviculture treatment on forest vegetation in CFM was very low. In addition, existing stock of thinned and unthinned block was not yet compare in the collaborative forest management. Thus, the study intends to fill the gap by assessing the condition of regeneration while applying different types of treatment and trees in thinned and unthinned block in Nepal. It provides more robust information on practices of scientific forest management. General public, foresters, policy makers, and other stakeholders could be benefited from findings of the study.

The following sections describe the study's methodology and illustrates the results. Finally, the paper concludes with result, discussion, and conclusion.

\section{Methods}

\section{Study area}

The study was carried out in natural forests in Tilaurakot Collaborative Forest Management of Kapilvastu, Nepal (Fig 1). The study site has a tropical monsoon climate with elevation from $200 \mathrm{~m}$ to $300 \mathrm{~m}$ from the sea level. The latitude of this area is $27035^{\prime} 8.13^{\prime \prime}$ to $27045^{\prime} 32.98$ " $\mathrm{N}$ and with the longitude of 8301'56.78" to 8309'6.49" E. Tilaurakot forest lies in East-West highway in between Balhundra River and Gorusinghe spreading in North and South direction so it can serve to manage the forest scientifically by involving stakeholder and people as per the collaborative management for social and economic development of forest product at national level. It consists of various tropical tree species like Sal (Shorea robusta) as a dominant species and followed by Sissoo (Dalbergia sissoo), Asna (Terminalia tomentosa), Amala (Phyllantus embeica), Bajhi (Anogeissus latifolia), Satisal (Dalberzia latifolia), and Barro (Terminalia bellirica).

\section{Data Collection and Analysis}

The data were collected in the year 2018. Individual plants were categorized into seedlings (height(ht) $<1.3 \mathrm{~m}$ ), Sapling (diameter at breast height $-\mathrm{dbh}$ ) $<10 \mathrm{~cm}$ and $\mathrm{ht}>1.3 \mathrm{~m}$ ), Poles ( $\mathrm{dbh}>10 \mathrm{~cm}$ but less than $30 \mathrm{~cm}$ ) and trees $(\mathrm{dbh}>30 \mathrm{~cm})$. Boundary survey was carried out with the help of geographical positioning system (GPS), and sample plots were laid out on the map using ArcGIS 10.2.1 software. Forest inventory with systematic random sampling was conducted for data collection. Eccentric 11 sample plots were 
taken from the harvested block and 30 from each of the thinned and unthinned blocks (Fig 2). Sampling intensity of $4 \%$ was taken for thinned and unthinned block, whereas $7 \%$ sampling intensity was taken in the harvested block. The height and dbh of trees, poles, and sapling were measured by using range finder and diameter tape, respectively. Plot sizes of $400 \mathrm{~m}^{2}$ with a radius of $11.29 \mathrm{~m}$ of circular plots were established in the forest to measure the $\mathrm{dbh}$ and height of trees. For pole, $100 \mathrm{~m}^{2}$ with radius $5.64 \mathrm{~m}$ plot size was taken and measured $\mathrm{dbh}$ and height of trees species. We only measured the $\mathrm{dbh}$ for sapling within radius $2.83 \mathrm{~m}$ plot size. We counted the number of seedlings within the plot $10 \mathrm{~m}^{2}$ with radius $1.78 \mathrm{~m}$. An area of $30 \mathrm{ha}$ was taken for thinned and unthinned block, whereas an area of 6ha was taken for the harvested block.

Growing stock and Basal area were calculated by using following formulas:

Basal area $=\mathrm{dbh}^{2} / 4$

(Source: Chaturvedi and Khanna 1994)

Growing stock=Basal area*height*form factor

(Source: DoF 2004)

In addition, Importance Value Index (IVI) was calculated to identify the relative abundance of the species in the study site. It is simply adding the percentage values of relative frequency, relative basal area, and relative density

Mathematically,

$\mathrm{IVI}=\mathrm{RF}+\mathrm{RB}+\mathrm{RD}$ (Kent and Coker, 1992).

where, RF is Relative Frequency

$\mathrm{RB}$ is Relative Basal Area

$\mathrm{RD}$ is Relative density

The secondary data related to the location of the forest, forest tree species, and relevant data had been collected using secondary source. Mainly secondary sources were district forest office, sector forest offices, concerned literature, libraries, and operational plans of CFM. For the statistical analysis, both descriptive, as well as inferential statistics, were used. At first, Kolmogorov Smirnov and Shapiro Wilk normality tests were performed to test whether the data were normal or not. Afterward, the parametric test, i.e. Independent samples t-test was performed and non-parametric, i.e. Mann- Whitney U test was performed for not normally distributed data.

\section{Results}

\section{Regeneration Status}


The status of regeneration in harvested block seems better as compared to thinned and unthinned blocks. Presence of quality seedling and sampling is one of the indicators of regeneration status. Table 1 presents the seedling and sampling count in three different blocks. The numbers of seedlings per hectare were found to be 14,947 , and the numbers of saplings were found to be 3,368 per hectare in harvested block. The regeneration status of seedlings was found to be 13,308 per hectare, and the numbers of saplings were found 1,846 per hectare in the thinned block. In the same way, regeneration of seedlings was found to be 10,000 and the numbers of saplings were found to be 1,320 per hectare in the unthinned block.

Table 1: Regeneration status in all three blocks; Harvested, Thinned and Unthinned Block

\begin{tabular}{|llll|}
\hline Regeneration & Harvested Block & Thinned Block & Unthinned Block \\
\hline Seedling (count per ha) & 14,947 & 13,308 & 10,000 \\
\hline Sampling (count per ha) & 3,368 & 1,846 & 1,320 \\
\hline
\end{tabular}

\section{Crop Stands in Thinned and Unthinned Block}

The condition of the crop stands can be measured by presence of growing stock and basal area in the forest. Our study compares such variables (basal area, growing stock, and number of stand) between the thinned and unthinned blocks (Table 2). The results in this study shows that the number of trees was higher in unthinned block (140 per ha) as compared to thinned block ( 86 per ha). Similarly, the number of poles in the unthinned (370 per ha) was higher than unthinned block (346 per ha). Also, the average growing stock for unthinned $\left(265.71 \mathrm{~m}^{3}\right.$ per ha) was a higher than thinned block $\left(174.9 \mathrm{~m}^{3}\right.$ per ha). According to the forest operation plan (2009), the average growing stock of Tilaurakot forest was found $165.25 \mathrm{~m} 3$ per

The basal area of thinned and unthinned block was $20.67 \mathrm{~m}^{2}$ per ha and $30.69 \mathrm{~m}^{2}$ per ha, respectively. This result shows that the basal area for the thinned block was lower than the unthinned block.

Table 2: Measurement of growing stock and Basal area in Thinned and Unthinned Block

\begin{tabular}{|lllllll|}
\hline Crops & \multicolumn{2}{l}{ Thinned Block } & \multicolumn{4}{l|}{ Unthinned Block } \\
\cline { 2 - 7 } & $\begin{array}{l}\text { Basal Area } \\
\left(\mathrm{m}^{2} / \mathrm{ha}\right)\end{array}$ & $\begin{array}{l}\text { Growing } \\
\text { Stock }\left(\mathrm{m}^{3} / \mathrm{ha}\right)\end{array}$ & $\begin{array}{l}\text { Crop stand } \\
\text { no./ha }\end{array}$ & $\begin{array}{l}\text { Basal Area } \\
\left(\mathrm{m}^{2} / \mathrm{ha}\right)\end{array}$ & $\begin{array}{l}\text { Growing Stock } \\
\left(\mathrm{m}^{3} / \mathrm{ha}\right)\end{array}$ & $\begin{array}{l}\text { Crop stand } \\
\text { no./ha }\end{array}$ \\
\hline Pole & 10.04 & 65.15 & 346 & 11.12 & 84.31 & 370 \\
\hline Tree & 10.63 & 109.82 & 86 & 19.57 & 181.40 & 140 \\
\hline Total & $\mathbf{2 0 . 6 7}$ & $\mathbf{1 7 4 . 9 7}$ & $\mathbf{4 3 2}$ & $\mathbf{3 0 . 6 9}$ & $\mathbf{2 6 5 . 7 1}$ & $\mathbf{5 1 0}$ \\
\hline
\end{tabular}


As compared to the three dominant species, S. robusta has maximum d.b.h. in both thinned and unthinned blocks. Similarly, S. robusta has a maximum height in both thinned and unthinned blocks. This result indicates that thinning enables both diameter and height growth for Sal. However, not necessarily maximum dbh has maximum height. This is because site quality was not properly correlated in the different block in different species and wind factor may also be the other reason. Table 2 shows the comparison of $\mathrm{dbh}$ and height of dominant three species in thinned and unthinned blocks.

Table 2: Measurement of Maximum Diameter and Maximum Height of Major Tree Species in Thinned Block

\begin{tabular}{|lllllllll|}
\hline Species & \multicolumn{2}{l}{ Max. dbh $(\mathrm{cm})$} & \multicolumn{2}{c}{ Dbh $(\mathrm{cm})$} & \multicolumn{2}{c|}{ Max. height $(\mathrm{m})$} & \multicolumn{2}{l|}{ Height $(\mathrm{m})$} \\
\cline { 2 - 7 } & Thinned & $\begin{array}{l}\text { Un } \\
\text { thinned }\end{array}$ & Thinned & $\begin{array}{l}\text { Un } \\
\text { thinned }\end{array}$ & Thinned & $\begin{array}{l}\text { Un } \\
\text { thinned }\end{array}$ & Thinned & $\begin{array}{l}\text { Un } \\
\text { thinned }\end{array}$ \\
\hline Sal & 82.82 & 68.79 & 49.36 & 65.61 & 26 & 20 & 24 & 18 \\
\hline Asna & 35.98 & 46.18 & 31.84 & 46.18 & 21 & 24 & 18 & 24 \\
\hline Sissoo & 50.32 & 38.22 & 33.44 & 38.22 & 25 & 20 & 18 & 20 \\
\hline
\end{tabular}

\section{Plant Diversity of Tilaurakot Forest}

The IVI indicates the structural importance of each species in the forest. The study illustrated that IVI of the $S$. robusta was a higher in all three different blocks as compared to T. tomentosa and other species. The IVI of major species in the harvested block was S. robusta 264.82, Asna (Terminalia tomentosa) 25.58 and other was species 39.92. The IVI in thinned block S. robusta 157.35, T. tomentosa 90.21 and other species was 96.34 whereas in the unthinned block IVI of S. robusta 274.29, T. tomentosa 42.92. The study suggests $S$. robusta is the dominant species in term of density and frequency. Also, the study conducted by Department of Forest Research and Survey (2014) found S. robusta was a prominent species which is followed by $T$. tomentosa in lowland of Nepal. Similar finding was illustrated in the study carried out by Awasthi et al. (2015). This study further performed the Mann-Whitney test for the comparisons of poles of different species between thinned and unthinned blocks. It was found that there was a significant difference among thinned and unthinned blocks for the occurrence of $S$. robusta $(p<0.056), T$. tomentosa $(p<0.001)$ and other species $(p<0.001)$. However, similar statistical test for the trees of different species in thinned and unthinned stands was no significant difference for $S$. robusta $(p<0.168)$ but was significant difference for T. tomentosa $(p<0.001)$ and other species $(p<0.010)$. This means that the regeneration of $S$. robusta pole crops were dominant, and the forest management operation was doing perfectly well.

\section{Discussion}

The status of regeneration in harvested block seems better as compared to thinned and unthinned blocks. Presence of quality seedling and sampling is one of the indicators of regeneration status. The 
number of per acre seedling and sapling was higher in harvested block than thinned and unthinned block in the study areas. A higher number of seedling and sampling per ha in harvested and thinned block suggest that open canopy favors the regeneration. A study carried out by Rai et al. (1999) found dense forest with a high density of larger trees was not favorable condition for natural regeneration. In addition, regeneration status is also determined by disturbance intensity (Sapkota et al. 2009). The study conducted by Khanal and Adhikari (2018) found that on average, number of seedlings per ha increased by 1.2 to 24 times due to regeneration felling in community forests of Rupandehi district. However, increase in number of samplings after regeneration felling was relatively less which ranges from 1.3 to 8.8 times (Khanal and Adhikari 2018). Our study shows that Tilaurakot CFM has good status of seedling and sapling. However, during the data collection time, regeneration in the harvested block was not found uniform. It was observed regeneration status varied between the plots of each blocks. However, this study fails to test the statistical significance within blocks. The success and failure of natural regeneration depends upon the locality factors. The study conducted by Negi et al. (2002) found that S. robusta borer (Hoplocerambyx spinicornis) and coupled with intensive grazing, unmanaged harvesting, and frequent forest firing were serious problem to damage $S$. robusta forest in India. In such condition, artificial regeneration such as seed sowing, seedling plantation could be applied to assist natural regeneration in making uniform and in increasing regeneration of the area. Also, regeneration can be established by protection against grazing and forest fire.

In the same way, crop stand (count per ha) is one of the key indicators for forest condition. This study reported that due to thinning practices, the number of tree and pole-sized stand was lesser in thinned areas. However, number of trees in thinned block still greater in number. Lewis et al. (2010) recommended that generally well-managed forest for timber production should have lower stocking (generally less than 200 trees per ha) and consists of good form trees and desirable species. The stocking ranges of between (80-150) trees per ha (>10 cm dbh) are common for well managed productive forests. The intent of thinning is to create a favorable environment to existing stands Therefore, trees need to be harvested according to the harvestable diameter as regeneration has already established and for the better growth of those regeneration exploitable diameter trees should be harvested in both thinned and unthinned block.

Another indicator of forest condition is growing stock ( $\mathrm{m}^{3}$ per ha). As our study disclosed that average growing stock in thinned block was lesser than unthinned block. However, the growing stock of the study site was still a higher in both types of block as compared to forest operational plan of whole Tilaurakot CFM (2009) and average growing stock of Nepal (164.46m³ per ha) (DFRS 2015). This result indicates the ratio of forest feelings to increment is relatively low. Our results suggest that forest products were underutilized. Since the intent of the establishment collaborative forest management was to fulfill the requirements of users, the CFM fails to supply forest products in the market.

Similarly, basal area ( $\mathrm{m}^{2}$ per ha) in thinned block was lesser than unthinned block. In addition, the study indicates that basal area of tree and pole-sized are same in thinned block, whereas basal area of tree stands was a higher than pole-sized stand in unthinned blocks. This result provides the evidence that 
number of pole-sized stand was a higher than tree in thinned block. As we compared our results with other studies. The basal area of the study area was a lower as compared to the study carried out in community forests by (Poudel and Mandel 2019). This is because that community forests have been managed and implemented the various silviculural operations. However, CFM did not apply any types of forest management practices. Basal area growth response was influenced by a reduction in competition (Gradel et al. 2017). The purpose of the execution of silvicultural operations is to improve the forest health.

As previous study (Sapkota 2009), S. robusta, IVI was a higher as compared to other species in all three blocks. It indicates that the study site was predominately by $S$. robusta because of its silvicultural characteristics such as light demander and establish aggressively by suckers. Although the rotation age of this species too long (approximately 80 years), the higher market value not only attracts the users but also the government for the management of $S$. robusta forests. Also, $S$. robusta is a naturally grown species that support the tropical biodiversity and ecosystem. Therefore, for regeneration management $S$. robusta must be given priority to maintain the existing ecological service of the forest.

The condition of forest types is influenced by thinning. The thinning favors the forest stands by reducing the competition, providing better sun light, and prevent against insect, diseases and fires. However, soil type, site index, topographic factors, aspects, and climatic condition are key factors in determining the growth and development of the forest stands. Thinning plays as a role of catalyst in improving forest conditions. Most important points of thinning in community managed forest is that thinning provide the supply of forest products such as pole, firewood, fodder for upliftment of the local people. Loss of biodiversity, prone to soil erosion, damage of water source, and habitat loss were some of the key issues of thinning practices in natural forests. To address the issue, it is necessary to comprehend the implications of thinning and execution of CFM concept in natural resource.

\section{Conclusions}

In summary, this study illustrated the effect of thinning in regeneration and existing stand condition. Regeneration status was good in harvested blocks. Crop stands was better in thinned blocks as compared with the unthinned blocks. Thus, finding concludes that thinning enhances the growth of the trees and undergrowth vegetation in regeneration layer. As the diversity index of $S$. robusta species was found more in different treatment block, it can be said that $S$. robusta was the dominant species of Tilaurakot CFM forest. In order to promote the good regeneration in unthinned block, the harvestable size of trees need to be removed or thinned. Also, the protection of harvested block against intensive grazing and forest fire should be implemented.

To carried out this study, three years old harvested block was taken. So, it might not represent the actual situation to predict for future regeneration. Future research needs to be carried out to show the effects of different treatment applied in the forest to promote regeneration, growing stock and height growth. 
Research related to numbers of trees and poles per ha be retained based on diameter class should be studied for the management of the forest.

\section{Abbreviations}

CFM: Collaborative Forest Management

SFM: Scientific Forest Management

Ha: Hectare

Ht: Height

DBH: Diameter at breast height

$M^{2}$ : Square meter

M: Meter

IVI: Important value index

RF: Relative frequency

RB: Relative basal area

RD: Relative density

$\mathrm{M}^{3}$ : Cubic meter

No: Number

CM: Centimeter

\section{Declarations}

\section{Acknowledgements}

The authors would like to express sincere thanks to the independent reviewers for providing valuable comments and suggestions to improve the quality of the manuscript.

\section{Funding}

The study is financially supported by Tilaurakot Collaborative Forest Management, Kapilvastu Nepal.

\section{Competing Interests}


The authors declare that they have no competing interests.

\section{References}

1. Acharya KP, Tamrakar PR, Gautam G, Regmi, R, Adhikari A, Acharya B (2002) Managing tropical sal forests (Shorea robusta) of Nepal in short rotations: findings of 12-year long research, Banko Janakari 12(1):71-75.

2. Awasthi N, Bhandari SK, Khanal Y (2015) Does scientific forest management promote plant species diversity and regeneration in Sal (Shorea robusta) forest: a case study from Lumbini Collaborative forest, Rupendehi, Nepal. Banko Jankari, 25(1): 20-29.

3. Bampton JFR, Ebregt A, Banjade M (2007) Collaborative Forest Management in Nepal's Terai: Policy, Practice, and Contestation. Journal of Forest and Livelihood, V0I 6, No. 2.

4. British Columbia. Ministry of Forest. Forest Practices Branch (2003) Silviculture Systems Handbook for British Columbia. For. Pract. Br., BC. Min. For., Victoria, BC. Canada.

5. CFM OP (2009) Tilaurakot Collaborative Forest Management operational plan. Government of Nepal. Ministry of Forest and Soil conservation, Kathmandu, Nepal.

6. Chaturvedi AN, Khanna LS (1994) Forest mensuration and biometry. Khanna Bandhu, Dehradun, India.

7. Curtis JT (1959) The vegetation of Wisconsin. An ordination of plant communities. Univ. Wisconsin. $657 p$.

8. DoF (2004) Community Forestry Inventory Guideline, Department of Forests, Community Forest Division, Nepal.

9. Gradel A, Ammer C, Ganbaatar B, Nadaldorj O, Dovdondemberel, B, Wagner S ( 2017) On the effect of thinning on tree growth and stand structure of White Birch (Betula platyphylla Sukaczev) and Siberian Larch (Larix sibirica Ledeb.) in Mongolia. Forests. 8: 105. doi:10.3390/f8040105

10. Ishlam R, Siwar C, Ismail SM, Chamhuri NH (2010) Criteria and Indicators for Sustainable Forest Management in Malaysia. American Journal of Environmental Sciences 3(6): 212-18.

11. Kent M, Coker P (1992) Vegetation Description and Analysis. A practical approach. John Wiley and Sons, New York, 363p.

12. Khanal $Y$ (2018) Analysis of the thinning in scientific forest management in Lumbini Collaborative Forest, 2018: District Forest Office, Rupandehi, Nepal.

13. Khanal $Y$ and Adhikari S (2018) Regeneration promotion and income generation through scientific forest management in community forestry: a case study from Rupandehi district, Nepal. Banko janakari 28(4): 48-49.

14. Kumar S (2002) Does "participation" in common pool resource management help the poor? A social cost-benefit analysis of joint forest management in Jharkhand, India. World Dev (30): 763-782.

15. Lewis T, Osborne D, Hogg B, Swift S, Ryan S, Taylor D, Macgregor-Skinner J (2010) Trees growth relationship and silviculture tools to assist stand management in private native spotted gum 
dominant forest in Queensland and northern New South Wales. Sustainability and Resource project. Project no. PNC075-0708.

16. Poudel P, Mandel RA ( 2019) Comparing Growing Stock using Circular, Square and Rectangular Plots Shape in Inventory (A study from Community Forests in Chitwan District, Nepal). Canadian Journel of Soil Science 4(1): 448-454

17. McDonald P, M Philip and Vaughn, NR (2007) Growth of Thinned and Unthinned Hardwood Stands on a Good Site in Northern California. United States Department of Agriculture, Forest Service. University of Washington, USA.

18. MFSC (2014) Scientific Forest Management guideline 2014. Ministry of Forest and Soil Conservation (MFSC) Kathmandu, Nepal.

19. Parajuli DP, Amatya SM (2001) Thinning in Natural Forests: An experience from Nepalgunj forest development project. Banko Janakari, 11(2): 42-43.

20. Pesonen P (1994) The Potential of the Natural Forest of the Terai and the New Principles of Forest Management. FMUDP Working Paper 15. Kathmandu, Nepal: Forest Management and Utilisation Project (FMUDP).

21. Pesonen P, Rautiainen O (1995) A Strategy for Managing Terai National Forest. Banko Jankari, 5(2): 59-63.

22. Kenna MCJ, Woeste K (2004) Fertilizing, Thinning and Pruning Hardwood Plantation. North Central Research Station, USDA Forest Service, Department of Forestry and Natural Resource, Prude University.

23. Poudel KC (2018) Silviculture for forest management in Nepal. Banko Jankari, 28(4): 15-19

24. Poudyal D (2007) Collaborative Forest Management in Nepal: Stepping towards managing productive forests of terai with social inclusion.

25. Rutt RL, Chhetri BB, Pokharel R, Rayamajhi S, Tiwari K, Treue T (2014) The scientific farming of forestry decentralization in Nepal. Forest Policy and Economics 60(11): 50-61.

26. Sowerwine D (1994) Forest sector potential and constraints. The Forestry Model and Report prepared by a consultant, Unpublished Report, Kathmandu.

27. Sapkota IP (2009) Species diversity, regeneration and early growth of Sal forests in Nepal: responses to inherent disturbance regimes. Doctoral Thesis. Swedish University of Agricultural Science, Alnarp.

\section{Figures}



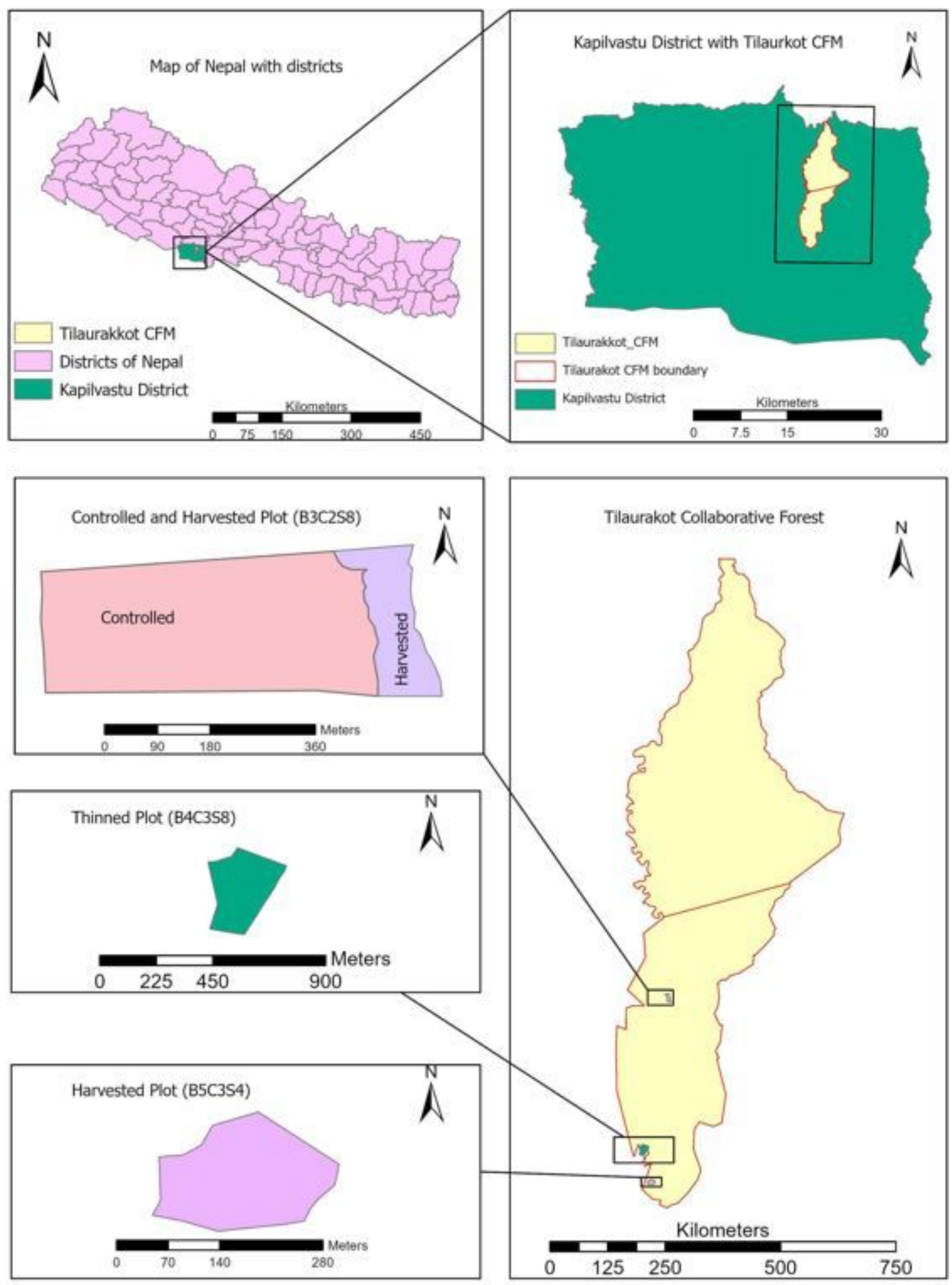

Figure 1

Map shows the detail study area. 


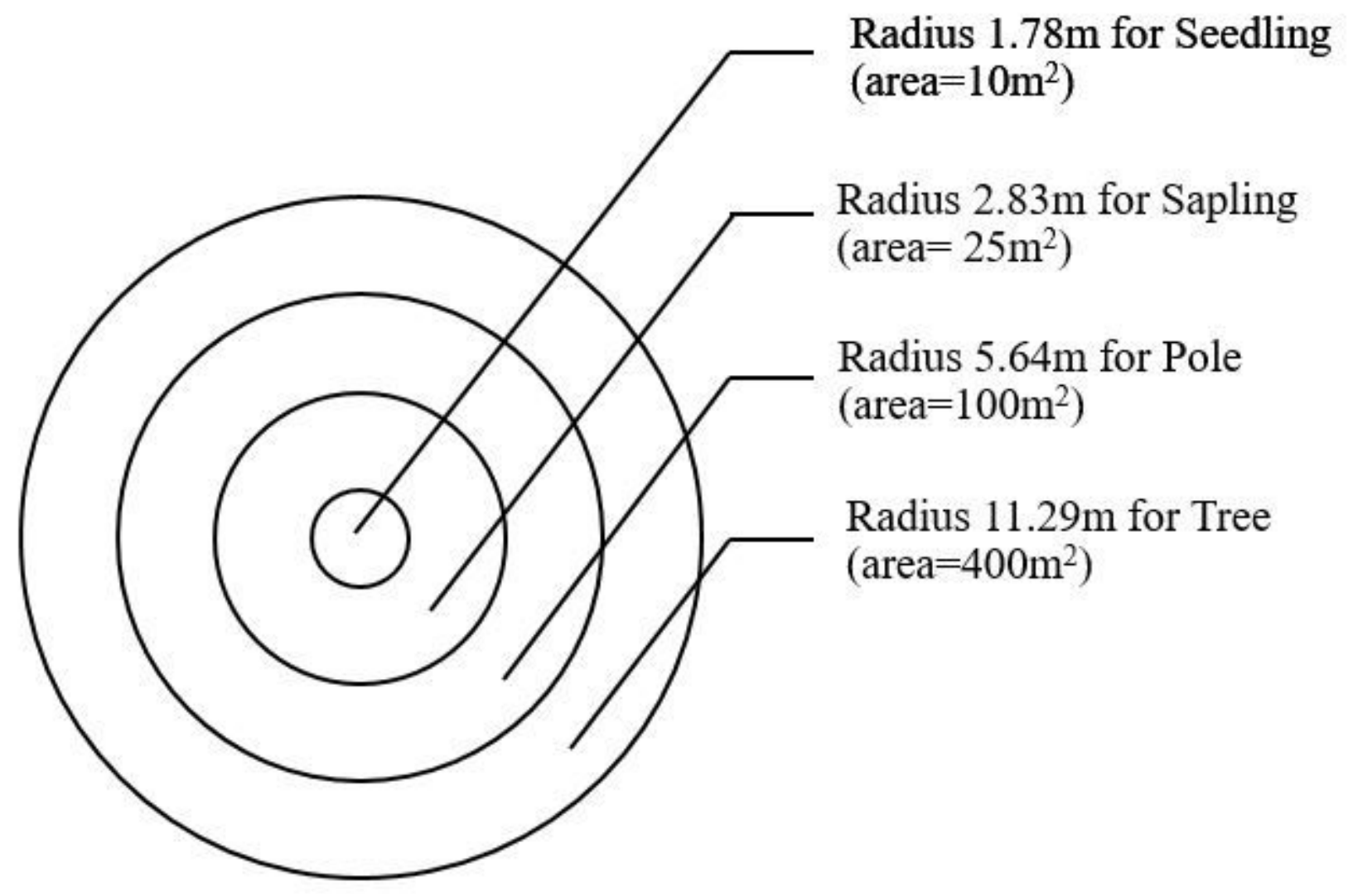

Figure 2

Eccentric sampling plots 